\section{Protocol for Genomic DNA Preparation from Fresh or Frozen Serum for PCR Amplification}

BioTechniques 29:460-466 (September 2000)

Blood is the primary human tissue for clinical diagnosis. Serum may be stored in banks after diagnosis, and most of the specimens may have available corresponding clinical records. These serum samples can be important sources of genomic DNA for human genetic studies in the identification of disease-causing genes or the study of mutations in prenatal diagnosis $(10,16)$, in the detection of tumor DNA from patients with pancreatic (12), lung (3), colorectal (1) and breast cancer (15). However, DNA isolation from serum is difficult because of the low content of
DNA in serum and the small amounts of serum that may be available.

Martin et al. (11) first described a procedure to isolate DNA for genotype analysis, and others have developed different methods for serum DNA isolation $(6,14)$. Dixon et al. (4) have tested 13 currently available DNA extraction methods. We have also reported a method for DNA extraction from small amounts of serum (9). However, for DNA analysis on a larger scale, a simple, automation-amenable protocol is required. In the present study, we describe a simple protocol for DNA preparation from serum. It includes only two steps, alkaline lysis and neutralization, with two different solutions in one tube.

Blood was collected in a red top $\mathrm{Va}$ cutainer (no additives) (Becton Dickinson, Franklin Lakes, NJ, USA) with a $22 \mathrm{G} 1$ needle and was allowed to clot at room temperature for at least $2 \mathrm{~h}$. The clot was detached from the wall of the tube by a wooden applicator stick and then kept at $4^{\circ} \mathrm{C}$ overnight. It was centrifuged at $700 \times g$ for $5 \mathrm{~min}$; the serum (supernatant) was collected and used for DNA extraction.

For alkaline lysis, $10 \mu \mathrm{L}$ serum were incubated with $1 \mu \mathrm{L} 0.2 \mathrm{M} \mathrm{KOH}$ at $37^{\circ} \mathrm{C}$ for $20 \mathrm{~min}$. During this treatment, various macromolecules in serum may be denatured or hydrolyzed (i.e., RNA) (7). To identify optimal conditions for the alkaline lysis, we tested different $\mathrm{KOH}$ concentrations $(0.1$ or $0.2 \mathrm{M})$ at different incubation temperatures $\left(55^{\circ} \mathrm{C}\right.$, $45^{\circ} \mathrm{C}$ or $37^{\circ} \mathrm{C}$ ). Ten microliters of serum were used, and the incubation time was $20 \mathrm{~min}$. To neutralize the solution, $5 \mu \mathrm{L}$ neutralization buffer $(9$ parts $1 \mathrm{M}$ Tris, $\mathrm{pH} 8.3: 1$ part $2 \mathrm{M} \mathrm{HCl}$ ) were added to the serum lysate and vortexed briefly. The final DNA solution volume was 16 $\mu \mathrm{L}$, and $3 \mu \mathrm{L}$ each condition were used for PCR amplification.

In this study, the target DNA se- 
quences were from human surfactant protein A (SP-A) (primers 26 and 28A) (13) and B (SP-B) (primers 71A, 73, $94,106,114,535$ and 536) (8). The primer sequences (lowercase letters indicate a non-gene-specific sequence attached to the gene-specific sequence for other purposes) were: primer 26 (forward) 5'-GCTTAGAGACAAAGTGGTCA-3'; primer 28A (reverse) 5' ACCCTCAGTCAGGCCTACAT-3'; primer 71A (reverse) 5'-ggggaattcAA TTGCTGCTCGGAGAGATC-3'; primer 73 (reverse) $5^{\prime}$-ctcgaatccCCAG CACCCTTCATTTCAGA-3'; primer 94 (forward) 5'-GAGGTGCCATGG CTGAGTCA-3'; primer 106 (reverse) 5'-GGCATCTGAGGGGATACAGC-3'; primer 114 (sense) 5'-ATTACAGGCATGTGCTACCA-3'; primer 535 (reverse) $5^{\prime}$-gcgactagtCTATGACGTCTG CTTCTCTGCCAAGGGAG-3'; and primer 536 (forward) 5'-gcggtcgacTCATCATGGTACTAATTCCTGCCCG TCCA-3'. Primers 535 and 536 were used for amplification in PCR 1 (PCR fragment is $10741 \mathrm{bp}$ ); 71A and 536 were used in PCR 2 (PCR fragment is 3792 bp); 106 and 114 in PCR 3(PCR fragment is $1656 \mathrm{bp}$ ); 73 and 94 in PCR 4 (PCR fragment is $1074 \mathrm{bp}$ ); and 26 and 28A in PCR 5 (PCR fragment is $220 \mathrm{bp}$ ).

One hundred nanograms of genomic
DNA prepared from whole blood (5) were used as control. The results from PCR amplification of two target DNA sequences (as shown in Figure 1) indicated that the optimal alkaline lysis condition was using $0.2 \mathrm{M} \mathrm{KOH}$ at $45^{\circ} \mathrm{C}$ for $20 \mathrm{~min}$. An incubation temperature of $55^{\circ} \mathrm{C}$ did not enhance the result obtained with $45^{\circ} \mathrm{C}$ (data not shown). Comparison of $37^{\circ} \mathrm{C}$ and $45^{\circ} \mathrm{C}$ incubation temperatures yielded similar results when $0.2 \mathrm{M} \mathrm{KOH}$ was used; therefore, for convenience, an incubation temperature of $37^{\circ} \mathrm{C}$ can be used.

The size of DNA sequences from serum DNA was subsequently examined, using long PCR (8) for amplification of all size fragments. The target gene sequence for this set of experiments was the surfactant protein B. As shown in Figure 2, it was possible to amplify from fresh serum (as opposed to archived frozen serum), DNA fragments of $3792 \mathrm{bp}$ and $1656 \mathrm{bp}$ (PCR 2 and PCR 3 , respectively) and a DNA fragment of $547 \mathrm{bp}$ with quantities similar to that observed with $100 \mathrm{ng}$ control DNA (PCR 4). However, it was not possible to amplify a 10741-bp fragment from serum DNA (PCR 1). Because genotype analyses usually require target sequences smaller than 1 $\mathrm{kb}$ (about $500 \mathrm{bp}$ ), the serum DNA preparation described here could be

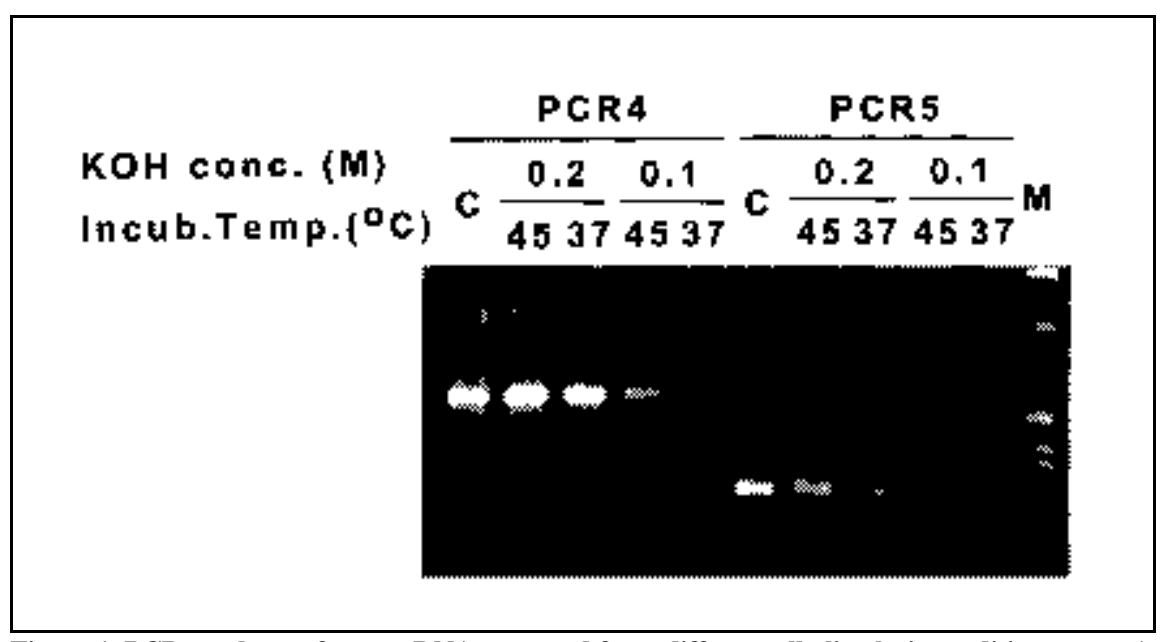

Figure 1. PCR products of serum DNA prepared from different alkaline lysis conditions. Ten microliters of serum were lysed with $1 \mu \mathrm{L} \mathrm{KOH}$ solution (concentration is 0.1 or $0.2 \mathrm{M}$ ) and incubated at different temperatures $\left(37^{\circ} \mathrm{C}\right.$ or $\left.45^{\circ} \mathrm{C}\right)$ for $20 \mathrm{~min}$. Three microliters of serum DNA were used for PCR. Genomic DNA (100 ng) prepared from whole blood (5) was used as control (C). The sizes of the PCR fragments are $547 \mathrm{bp}$ (PCR 4) and $220 \mathrm{bp}$ (PCR 5). The PCR profile was $95^{\circ} \mathrm{C}$ for $2 \mathrm{~min}, 40$ cycles of $95^{\circ} \mathrm{C}$ for $30 \mathrm{~s}, 55^{\circ} \mathrm{C}$ for $1 \mathrm{~min}, 70^{\circ} \mathrm{C}$ for $1 \mathrm{~min}$, followed by $72^{\circ} \mathrm{C}$ for $2 \mathrm{~min}$, and the PCR products were electrophoresed on a $1 \%$ agarose gel. The DNA standard is a 1-kb ladder (M) (Life Technologies, Rockville, MD, USA). widely applied to other genetic studies.

Serum DNA stability was tested by storing the DNA at $4^{\circ} \mathrm{C}$ and $-20^{\circ} \mathrm{C}$. The stability of serum DNA was assessed by studying PCR products amplified from serum DNA stored under various conditions. The results indicate that serum DNA is stable for up to four months at $-20^{\circ} \mathrm{C}$, but a significant decline in stability is observed after one month if the DNA is stored at $4^{\circ} \mathrm{C}$ (data not shown).

Moreover, we have used serum collected several years ago (i.e., archived) to extract DNA and then perform genotype analysis as part of another study (data not shown). Using the protocol described here, we have analyzed genotypes at 9 single-nucleotide polymorphisms (SNPs) in SP-A, 4 SNPs in SP-B, 2 SNPs in SP-D and 4 microsatellite markers in SP-B flanking region from more than 10 fresh and more than 60 frozen archived serum samples. The genotyping method we used was PCRbased converted RFLP. The target DNA fragments were 51-354 bp. Using nested PCR, the target fragments, even from frozen samples, were successfully am plified in $96 \%$ of the cases. However,

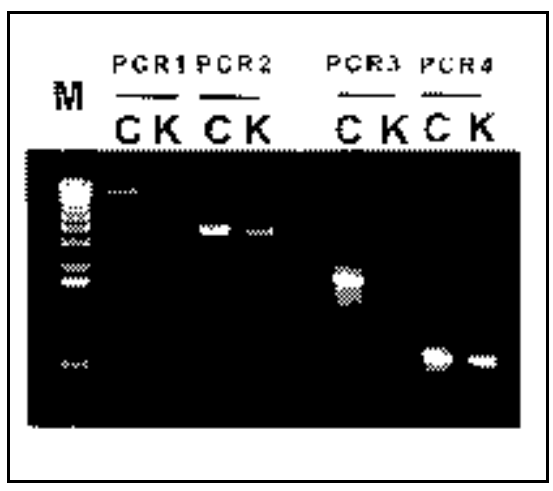

Figure 2. Sizes of target DNA sequences amplified from serum DNA preparation. Ten microliters of serum and $1 \mu \mathrm{L} 0.2 \mathrm{M} \mathrm{KOH}$ were incubated at $37^{\circ} \mathrm{C}$ for $20 \mathrm{~min}$, and $5 \mu \mathrm{L}$ neutralization buffer were then added. Three microliters of serum DNA were used for PCR (K). Control DNA (C) is 100 ng genomic DNA prepared from blood (5). The sizes of PCR fragments are 10741 bp (PCR 1), 3792 bp (PCR 2), 1656 bp (PCR 3) and $547 \mathrm{bp}$ (PCR 4). PCR was carried out using Expand $^{\mathrm{TM}}$ (Roche Molecular Biochemicals, Indianapolis, IN, USA) as described by Lin et al. (8). The PCR profile was $95^{\circ} \mathrm{C}$ for $2 \mathrm{~min}, 10$ cycles of $95^{\circ} \mathrm{C}$ for $30 \mathrm{~s}, 55^{\circ} \mathrm{C}$ for $1 \mathrm{~min}, 68^{\circ} \mathrm{C}$ for $10 \mathrm{~min}$, 20 cycles of $95^{\circ} \mathrm{C}$ for $30 \mathrm{~s}, 60^{\circ} \mathrm{C}$ for $1 \mathrm{~min}, 68^{\circ} \mathrm{C}$ for $12 \mathrm{~min}$, followed $68^{\circ} \mathrm{C}$ for $20 \mathrm{~min}$, and the PCR products were electrophoresed on a $1 \%$ agarose gel. The DNA standard is a 1-kb ladder (M) (Life Technologies). 


\section{Benchmarks}

we did observe PCR-generated loss of heterozygosity $(\mathrm{LOH})$. This is usually caused by the low amount of DNA in serum, as suggested by Bluteau et al. (2). We also found that the PCR-generated $\mathrm{LOH}$ could be overcome through a marker-specific PCR optimization strategy. Therefore, we suggest that different PCR strategies or genotyping methods should be considered and tested before starting large-scale genotype analyses from serum DNA.

From the results described above, we conclude that $(i)$ a simple protocol can be used for DNA extraction from serum. The entire procedure is carried out in two steps with two different solutions in one tube; (ii) the protocol can be easily automated; (iii) the quality of fresh serum DNA under the experimen- tal conditions presented here is adequate to be used as a template to amplify a few kilobases of target DNA sequence. However, if nested PCR is used and the target PCR fragments are about $500 \mathrm{bp}$, the quantity of PCR products from fresh or archived serum samples is similar to that obtained from $100 \mathrm{ng}$ control genomic DNA; and (iv) the protocol is suitable for microextraction. DNA can be prepared from as small a volume as $10 \mu \mathrm{L}$ serum and can serve as PCR template in five reactions. Generally speaking, DNA quantities equivalent to $2 \mu \mathrm{L}$ serum can be used as tem plate in one reaction for either one SNP or one microsatellite marker.

In summary, serum can serve as a source of DNA for PCR. It is likely that serum is a more reliable source for small DNA target sequences (less than 500 bp) rather than larger target sequences.

\section{REFERENCES}

1.Anker, P., F. Lefort, V. Vasioukhin, J. Lyautey, C. Lederrey, X.Q. Chen, M. Stroun, H.E. Mulcahy and M.J. Farthing. 1997. Kras mutations are found in DNA extracted from the plasma of patients with colorectal cancer. Gastroenterology 112:1114-1120.

2.Bluteau, O., P. Legoix, P. Laurent-Puig and J. Zucman-Rossi. 1999. PCR-based genotyping can generate artifacts in $\mathrm{LOH}$ analyses. BioTechniques 27:1100-1102.

3.Chen, X.Q., M. Stroun, J.L. Magnenat, L.P. Nicod, A.M. Kurt, J. Lyautey, C. Lederrey and P. Anker. 1996. Microsatellite alterations in plasma DNA of small cell lung cancer patients. Nat. Med. 2:1033-1035.

4.Dixon, S.C., J. Horti, Y. Guo, E. Reed and W.D. Figg. 1998. Methods for extracting and amplifying genomic DNA isolated from frozen serum. Nat. Biotechnol. 16:91-94.

5.Floros, J., S.V. Veletza, P. Kotikalapudi, L. Krizkova, A.M. Karinch, C. Friedman, S. Buchter and K. Marks. 1995. Dinucleotide repeats in the human surfactant protein B gene and respiratory distress syndrome. Biochem. J. 305:583-590.

6.Fowke, K.R., F.A. Plummer and J.N. Simonsen. 1995. Genetic analysis of human DNA recovered from minute amounts of serum or plasma. J. Immunol. Methods 180:45-51.

7.Leitzel, K., B. Lieu, E. Curley, J. Smith, V. Chinchilli, W. Rychlik and A. Lipton. 1998 Detection of cancer cells in peripheral blood of breast cancer patients using reverse transcription-polymerase chain reaction for epidermal growth factor receptor. Clin. Cancer Res. 4:3037-3043.

8.Lin, Z., D.E. deMello, M. Wallot and J. Floros. 1998. An SP-B gene mutation responsible for SP-B deficiency in fatal congenital alveolar proteinosis: evidence for mutation hotspot 
in exon 4. Mol. Genet. Metab. 64:25-35.

9.Lin, Z. and J. Floros. 1998. Genomic DNA extraction from small amounts of sera to be used for genotype analysis. BioTechniques 24:937-940.

10.Lo, Y.M., N.M. Hjelm, C. Fidler, L.L. Sargent, M.F. Murphy, P.F. Chamberlain, P.M. Poon, C.W. Redman and J.S. Wainscoat. 1998. Prenatal diagnosis of fetal RhD status by molecular analysis of maternal plasma. N. Engl. J. Med. 339:1734-1738.

11.Martin, M., M. Carringon and D. Mann. 1992. A method for using serum as a diagnosis test for congenital cytomegalovirus infection. J. Clin. Microbiol. 33:3317-3318.

12.Mulcahy, H. and M.J. Farthing. 1999. Diagnosis of pancreatico-biliary malignancy: detection of gene mutations in plasma and stool Ann. Oncol. 10:114-117.

13. Rishi, A.D., D. Hatzis, K. McAlmon and J. Floros. 1992. An allelic variant of the 6A gene for human surfactant protein A. Am. J. Physiol. 262:L566-L573.

14.Sanford, A.J. and P.D. Pare. 1997. Direct PCR of small genomic DNA fragments from serum. BioTechniques 23:890-892.

15.Silva, J.M., G. Dominguez, J.M. Garcia, R. Gonzalez, M.J. Villanueva, F. Navarro, M. Provencio, S. San Martin et al. 1999. Presence of tumor DNA in plasma of breast cancer patients: clinicopathological correlations Cancer Res. 59:3251-3256.

16.Smid, M., F. Lagona, L. deBenassuti, A. Ferrari, M. Ferrari and L. Cremonesi. 1999. Evaluation of different approaches for fetal DNA analysis from maternal plasma and nucleated blood cells. Clin. Chem. 45:15701572.

This work was supported by National Institutes of Health grant no. R37 HL34788 to J.F. Address correspondence to Joanna Floros, Ph.D., Professor, Department of Cellular \& Molecular Physiology, M.C. \#H166, The Pennsylvania State University College of Medicine, 500 University Drive, Hershey, PA 17033, USA. e-mail: jfloros@psu.edu

Received 26 October 1999; accepted 14 April 2000.

\section{Zhenwu Lin and Joanna Floros}

The Pennsylvania State

University College

of Medicine

Hershey, PA, USA

\section{Rapid Mini-Scale Plasmid Isolation for DNA Sequencing and Restriction Mapping}

BioTechniques 29:466-468 (September 2000)

A frequently used step in most molecular biological investigations is screening large numbers of recombinant plasmids to examine the size, orientation and nucleotide sequence of cloned inserts. The screened clones often serve as templates in PCR to generate DNA fragments that are subsequently processed for any number of studies such as subcloning into specialized vectors, assaying for biological activity and detecting cognate binding sites for regulatory proteins. The currently available "miniprep" plasmid purification procedures use differential DNA precipitation with polyethylene glycol and/or phenolchloroform extraction for the removal of many contaminants (4). These procedures are not entirely satisfactory because they are time consuming, tedious and require the use of expensive and undesirable chemicals.

Alternatively, it has been reported that plasmids released into the supernatant recovered from boiled bacterial suspensions can be used directly for restriction enzyme analysis (5). However, the quality of DNA is not suitable for analyses such as DNA amplification and sequencing. Commercially available miniprep kits are costly and do not provide a simple enough isolation protocol for routine screening and analysis of large numbers of clones. We have developed a modified version of the alkaline lysis method (1) for plasmid isolation in high enough yield and purity so that, without further purification, the retrieved plasmids can be used in a variety of experimental manipulations such as ligation, bacterial transformation, restriction mapping, PCR amplification and DNA sequencing.

Our approach (Protocol 1) differs from the commonly followed alkaline lysis protocol in that ribonuclease $\mathrm{A}$ (RNase A) is added to the initial bacterial resuspension buffer. We find that including RNaseA from the beginning helps to keep the contaminants in the solution phase. RNaseA treatment sim plifies the final step of DNA recovery because it prevents co-precipitation of contaminants that may interfere in subsequent enzymatic analyses. In addition, it allows the DNA to rapidly migrate into the solution phase. Our method has the additional advantages that $(i)$ no phenol-chloroform extraction is needed, (ii) each centrifugation step is only 1 min or less and (iii) the entire procedure can be carried out at room temperature instead of $4^{\circ} \mathrm{C}$.

Figure 1 shows comparative restriction enzyme digestion patterns of the same recombinant plasmid (pGEM3ZHNF3 $\beta$ ) prepared using three different isolation protocols: (i) a commercial miniprep DNA purification kit (Wizard ${ }^{\circledR}$ Plus SV miniprep system; Promega, Madison, WI, USA); (ii) our method as presented in Protocol 1; (iii) the conventional alkaline lysis method combined with phenol-chloroform extraction and DNA precipitation by polyethylene glycol. In all three cases, cleavage by different restriction enzymes generates very similar digestion

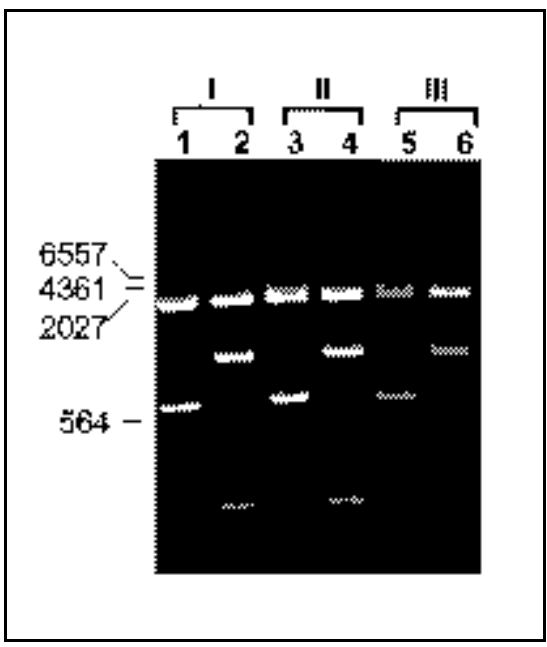

Figure 1. Comparative analysis of restriction enzyme cleavage patterns for the same pGEM3Z-HNF3 $\beta$ plasmid isolated by three different procedures. (I) Commercial miniprep kit; (II) our isolation scheme as detailed in Protocol 1 and (III) conventional alkaline lysis combined with phenolchloroform extraction and DNA precipitation by polyethylene glycol. Plasmid samples from different isolation methods were digested with NarI (lanes 1, 3 and 5) or PstI (lanes 2, 4 and 6). The digested samples were run on a $1 \%$ agarose gel, and the DNA bands were visualized by ethidium bromide staining. The lines in the left are the migration positions of marker DNA fragments, and the numbers indicate marker sizes in base pairs. 